\title{
Quaternary colluvial episodes (Upper Paraná River Hydrographic Basin, Brazil)
}

\author{
ALETHEA E.M. SALLUN ${ }^{1}$ and KENITIRO SUGUIO ${ }^{2,3}$ \\ ${ }^{1}$ Instituto Geológico (IG/SMA-SP), Av. Miguel Stéfano, 3900, Água Funda, 04301-903 São Paulo, SP, Brasil \\ ${ }^{2}$ Instituto de Geociências (USP), Rua do Lago, 562, Cidade Universitária, 05508-080 São Paulo, SP, Brasil \\ ${ }^{3}$ Universidade Guarulhos (CEPPE), Rua Nilo Peçanha, 81, Centro, 07023-070 Guarulhos, SP, Brasil
}

Manuscript received on April 18, 2009; accepted for publication on September 3, 2009

\begin{abstract}
Colluvial deposits occur extensively in the Upper Paraná River Hydrographic Basin (UPRHB) in Southeastern, Southern, and Western central Brazil. These deposits were recognized as an allostratigraphic unit and related to creeping during the Quaternary. Every studied colluvial profile is homogeneous, which indicates relatively long periods of landscape stability that is sufficient for the development of a thick soil cover. The deposits were dated by luminescence and indicate periods of more intense colluvial deposition between 6 and 220 ky B.P. These events correspond approximately to the transitions between the oxygen isotope stages 2-3-4 and 5-6, suggesting that this aggradation was influenced by climatic changes. However, the most important alluviation episode was tentatively correlated with the Middle to Upper Pleniglacial of the Wisconsin glaciation. The most intensive and frequent periods of precipitation that occurred during climate transitions are probably correlated with aggradation events. The regularity of the colluvial deposits suggests continuous uplift accompanied by sediment deposition throughout the UPRHB due to neotectonic activity during the last million years.
\end{abstract}

Key words: colluviation, alluviation, Quaternary, luminescence dating, Brazil.

\section{INTRODUCTION}

Eustasy plays an important role in the stratigraphic organization of marine sedimentary environments, but in continental depositional environments, climate and/or tectonic controls predominate (Shanley and McCabe 1994). The erosional and depositional processes that prevail in the Upper Paraná River Hydrographic Basin (UPRHB) are not restricted to the present, but occurred during most of the Quaternary. These processes generated colluvial and alluvial deposits over the entire hydrographic basin currently represented by the Upper Paraná River Allogroup (Sallun et al. 2007b). Local studies of the colluvial deposits are relatively common, but regional investigations are scarce.

Correspondence to: Alethea Ernandes Martins Sallun E-mail: alethea@igeologico.sp.gov.br
In the past, it was not possible to obtain absolute ages of colluvial deposits, due to the absence of adequate samples for radiocarbon dating, which is commonly lacking in sediments that accumulated after erosion. Luminescence has been used by several authors to date colluvial deposits (Lang 1994, Lang and Hönscheidt 1999, Eriksson et al. 2000, Yanchou et al. 2002, Lang 2003), with excellent results when the ages were compared with radiocarbon data (Clarke 1996, Lang and Wagner 1996). These methods are becoming much more important in the study of colluvial deposits because they are suitable in any situation when quartz grains are available and, in contrast to techniques that estimate synchronicity between relief stability and soil development, the luminescence ages indicate the sedimentation episode. In spite of favorable aspects of luminescence 
dating, the effects of insufficient exposure of the quartz grains to solar radiations can result in overestimated ages of colluvial deposits (Murray et al. 1995, Olley et al. 1998, Eriksson et al. 2000, Yanchou et al. 2002).

The first step for the regional analysis is to compile the chronological data on cumulative frequency curves, which provides a more complete picture than local analysis. However, the available data at the regional scale are restricted, and all events are not recorded in the colluvium. Moreover, the colluviation rate or quantity of sedimentation by time interval can hardly be estimated. Lang (2003) in southern Germany, and Hanson et al. (2004) in Wyoming (USA) were able to identify regional patterns in colluvial deposits from the distribution of luminescence dating data.

In addition, the colluvial deposits are geoarchives that might record information about climate (Leopold and Völkel 2007) because they are influenced by climatic processes. Solving these events and processes requires additional studies, but in together with field evidence and possible paleoclimate proxy records the colluvial deposits can provide data about the processes of erosion, transportation, and deposition during the time of its formation (partly controlled by paleoclimatic parameters) (Leopold and Völkel 2007).

The colluvial sediments were studied due to their short distance of transport, the easy identification of their source rock, and their application in the understanding of regional environmental changes. Nevertheless, dating of the colluvium generally results in only maximum ages of the material because of constant reworking over time.

\section{Paleoclimate versus Colluviation}

The paleoclimatic record includes cyclic and gradual changes with different intensities and frequencies through time, and it is controlled by astronomical, geophysical, and geological phenomena. These changes are not due to an unique cause but are, rather, multicausal, and they act at different temporal and spatial scales. According to Milankovitch's (1920) astronomical theory, the insulation or effective solar radiation incidence on the Earth's surface depends on the following planetary parameters: terrestrial orbit and centricity (0 to 0.067$)$, elliptical obliquity $\left(21.5^{\circ}\right.$ to $\left.24.5^{\circ}\right)$, and equinoxial (seasonal) precessions.
Broecker (1965) recalculated and confirmed Milankovitch's (1920) curve, and it generally showed good correlations with other paleoclimatic factors. The astronomical theory offers a coherent explanation for the sequence of main paleoclimatic functions, including the Quaternary glaciations, but there is no doubt that other factors also influenced global changes of the climate in this period. $\delta^{18} \mathrm{O}(\%)$ values of deep water submarine cores have allowed the recognition of cold and warm phases during the Quaternary (Emiliani 1955), as a consequence of global paleoclimatic changes represented by glacial (even numbers) and interglacial (odd numbers) stades extending to the Upper Pliocene (Shackleton and Opdyke 1976, Shackleton 1997). In the $\delta^{18} \mathrm{O}(\% 0)$ curves, the glacial-interglacial transitions are sharper than the interglacial-glacial transitions because the glaciers expanded slowly but disappeared more rapidly. Broecker and Van Donk (1970) denoted the sudden glacial-interglacial change as "glacial termination", subdividing the curve into glacial-interglacial stades.

Ages obtained through luminescence dating have been used to date the aggradation pulses of colluvial and alluvial sedimentation and to establish their possible correlations with global climatic changes. At the beginning of the arid climate, which would have begun a glacial stade, the reduced vegetation cover would have exposed the soils and made them more vulnerable to erosion, which would cause rapid reworking of the sediments from slopes during the climatic transition (Wells et al. 1987, Bull 1991). Knox (1972) developed a model to explain the more frequent and intense pulses of sediments generated by slopes during the Holocene in Wisconsin (USA), where the precipitation increase caused a quick leveling of slope sediments, and the major vegetation density along stable slopes could have reduced the quantity of available sediments. The models suggested less accentuated erosion under stable climates and more abundant sedimentation during climatic transitions. Nevertheless, few studies have referred to colluvial sedimentation increases during climatic transitions through direct dating of the colluvial sediments. This study tentatively suggests a possible synchronicity between colluvial deposition in the UPRHB and the arrival of colluvial sediments generated during millennial-scale climatic transitions. 

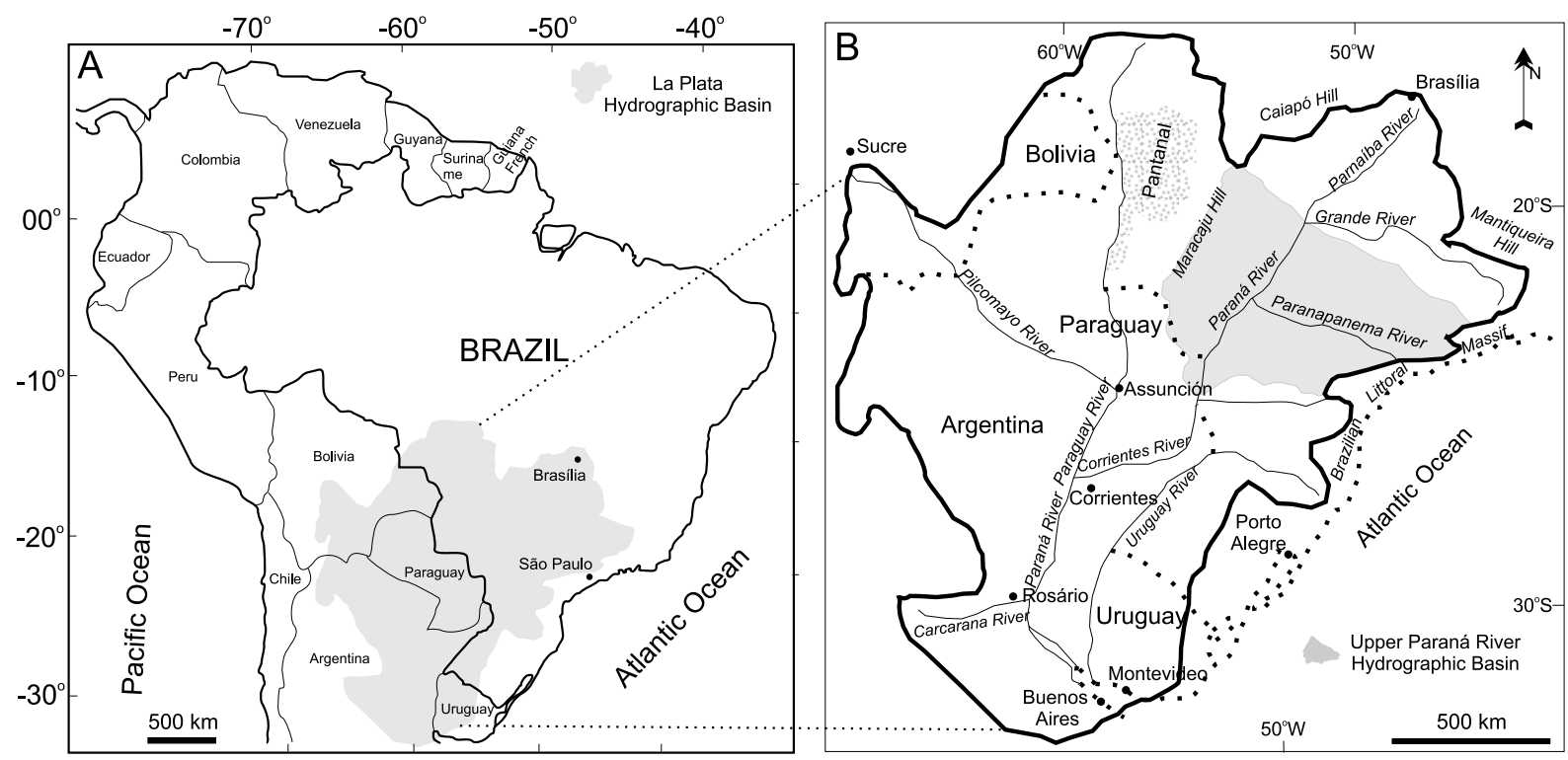

Fig. 1 - Geographic location map of the La Plata Hydrographic Basin in South America (A), emphasizing the UPRHB (B).

\section{STUDY AREA}

The Paraná, Paraguay, La Plata, Pilcomayo, and Uruguay Rivers, form the La Plata River Hydrographic Basin (Fig. 1). According to different characteristics, the Paraná River can be divided into five segments. This study was done in the sector called the "Upper Paraná River", which extends for about $619 \mathrm{~km}$ in the Southeastern, Southern, and Western-central regions of Brazil. The main geographic limits of the UPRHB are the Grande and Paranaíba Hydrographic Basins and Serra do Caiapó to the north, the Brazilian Littoral Massif (Serra do Mar) to the east, the Iguaçu River Hydrographic Basin to the south, and the Paraguay River Hydrographic Basin and Serra de Maracaju to the west. Due to differences in the uplift rates among the main rivers, tributaries in the eastern margin, whose headwaters are situated in the Littoral Massif crystalline rocks, are 400 to $600 \mathrm{~km}$ longer in comparison to the longest right margin tributaries. The latter with lengths less than $400 \mathrm{~km}$, are situated in the Paraná Sedimentary Basin with their headwaters placed at Serra de Maracaju and Serra do Caiapó (Stevaux 2000).

As a consequence of the uplift of the Brazilian Littoral Massif, intense erosional processes were established during the Neogene in the UPRHB, causing the formation of several mapable depositional units (Almeida 1983). These units are associated with erosional cy- cles and the generation of flat surfaces, such as the pediplains $\mathrm{Pd}_{1}, \mathrm{Pd}_{2}$, and $\mathrm{Pd}_{3}$ (Bigarella and Andrade 1965) and $\mathrm{Pd}_{0}$ (O.J. Justus 1985, unpublished data) or "South American Surface", the Velhas and Paraguaçu cycles (King 1956, 1967), or surfaces of "High Interfluves", "Middle Interfluves", and "Upper Terrace" (Soares and Landim 1976), and the "Guaíra Surface" (Barthelness 1960).

\section{GEOLOGICAL CONTEXT}

In the study area, Quaternary deposits overlie Cretaceous sandstones (Bauru Supersequence) and basalts (Gondwana III Supersequence), both belonging to the Paraná Sedimentary Basin (Renne et al. 1992, Dias Brito et al. 2001). Sallun et al. (2007b) formally proposed the Upper Paraná River Allogroup as Quaternary stratigraphic units that occur overlying Cretaceous rocks of the Paraná Basin in the UPRHB (Fig. 2). The Upper Paraná River Allogroup is composed of colluvial (Paranavaí Alloformation) and alluvial (Paraná Alloformation) deposits. The Cretaceous sedimentary rocks are essentially sandy and, therefore, the colluvial and alluvial Quaternary deposits are also relatively homogeneous (grain-size distribution and mineralogical characteristics).

The Paranavaí Alloformation is made up of homogeneous and massive arenaceous and rudaceous deposits exposed in outcrops up to $17 \mathrm{~m}$ thick. They are composed 


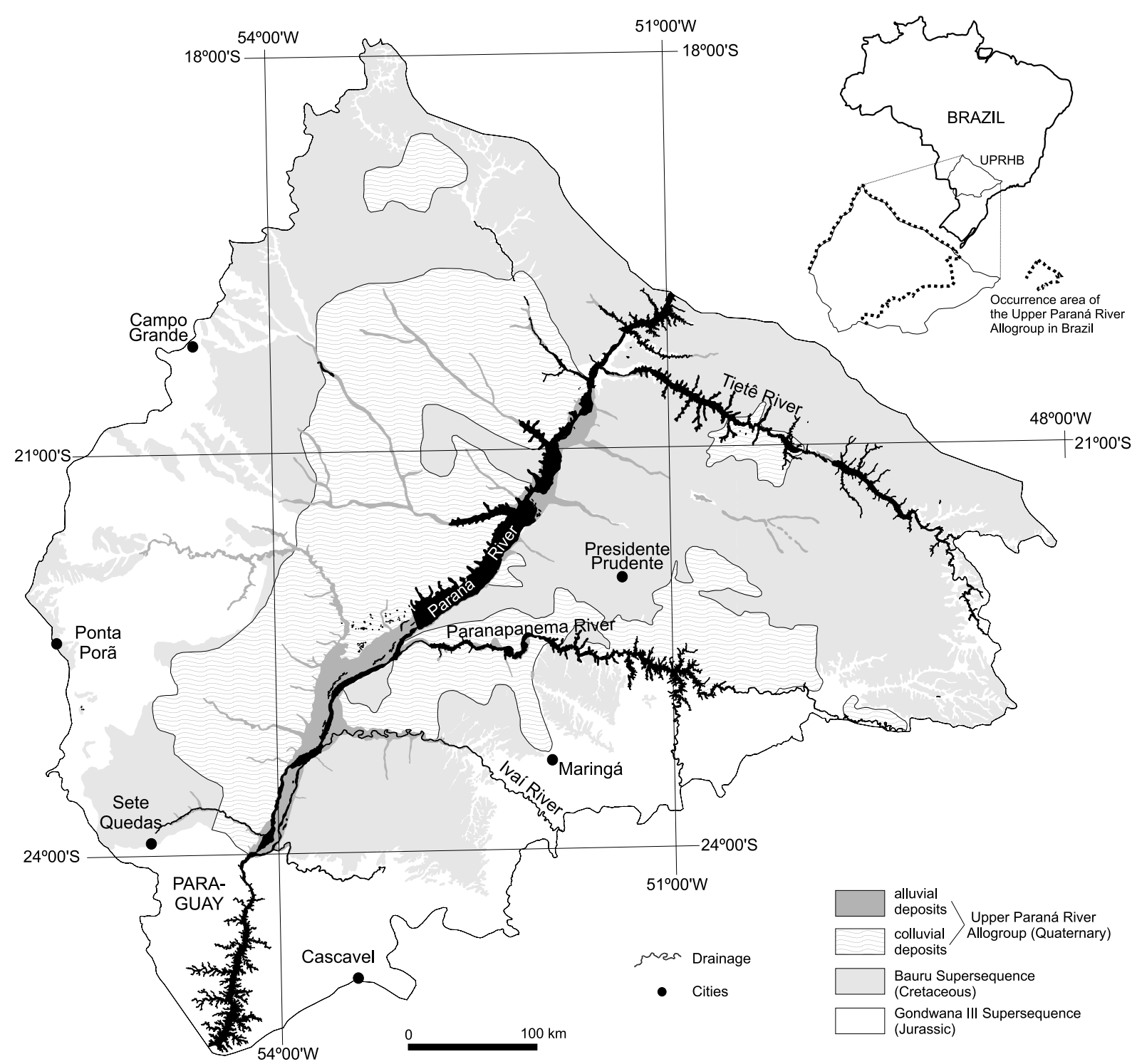

Fig. 2 - Geologic map of the occurrence of the Upper Paraná River Allogroup in the UPRHB according to Sallun et al. (2007a).

of unconsolidated, reddish-colored, very fine to coarse sands. The upper boundary corresponds to a horizon formed by present pedogenesis, and the lower boundary is represented by the contact with the Paraná Basin Cretaceous rocks of Bauru and Gondwana III Supersequences, which includes centimetric ferricrete nodules and stonelines.

The Paranavaí Alloformation colluvial deposits are mainly composed of sandy and clayey sandy. There are also rudaceous deposits, superimposed on Cretaceous rudaceous deposits of the Bauru Group, which are indicative of deep weathering of the Marília Formation, being probably formed in place or after transportation for a short distance by creeping. In general, they are oligomictic ortoconglomerates without internal arrangement that contain clasts from granules to subrounded to rounded boulders, properties that were probably inherited from the source rock (Sallun and Suguio 2008, Sallun et al. 2008). The fragments exhibit punctual and locally concave-convex contacts whose longest diameter can reach $1 \mathrm{~cm}$. The pebbles are dominated by quartz and quartzite, in addition to scarce cherts and basalts. The clayey matrix does not exceed $15 \%$ and, moreover, contains $15 \mathrm{~cm}$ thick sandy bed intercalations. 
The Paraná Alloformation is composed of alluvial deposits associated with the Upper Paraná paleodrainage, besides the present course and tributaries, preserved as terraces or modern alluvial deposits of the Upper Paraná River tributaries within the Paranavaí Alloformation. The fluvial terraces are situated in several topographic levels (high, middle and low) along both margins of the Paraná River. The terraces are made up of sandy and pebbly deposits (sand with gravel and ironhydroxide cemented conglomerates), massive, whitishto dark grayish-colored facies, which are suggestive of channel, sandy sheet, floodplain, natural levee, crevasse splay, and point-bar deposits (Stevaux 2000). The lacustrine deposits formed on the Paranavaí Alloformation are also included in the Paraná Alloformation.

Geoprocessing techniques were used for mapping the distribution of Quaternary deposits of the Alto Rio Paraná Allogroup within the UPRHB (Sallun et al. 2007a). Through data crossing obtained by field surveys, remote sensing products and thematic maps using Geographic Information System (GIS), the morphostratigraphic characteristics of this allostratigraphic unit and their relationship with erosional surfaces were identified (Sallun et al. 2007a).

The occurrences of different lithoestratigraphic units in the Paraná Basin, as well as regional tectonic structures and differences in thicknesses of colluvial Paranavaí Alloformation and alluvial Paraná Alloformation, are responsible for the relief compartimentation. The surface is mainly composed of very flat hills conditioned by thicker Paranavaí Alloformation colluvial deposits, which gives rise to lower declivity and rugosity of extensive hillslopes (Sallun et al. 2007a).

\section{MATERIALS AND METHODS}

Due to the low diversity of Quaternary sedimentary deposits in the area, the colluvial deposits are the most important stratigraphic record. They are abundantly distributed throughout the study area. Moreover, they can be dated by luminescence methods back to about $1 \mathrm{My}$ (Tatumi et al. 2006). All the luminescence dates obtained to date were gathered here to attempt a regional analysis of the chronological data.

In this study, Thermoluminescence (TL) and Optically Stimulated Luminescence (OSL) methods are used to date the last exposure of the quartz grains in the colluvium to sunlight. Before sampling, the outcrop surfaces were grazed for removal of more leached superficial materials to avoid contamination by inclusion of mineral grains with different ages. The samples were collected with opaque PVC tubes, which were introduced horizontally by percussion with a hammer.

The TL and OSL dating were carried out at the Laboratory of Glasses and Dating of the Faculdade de Tecnologia de São Paulo, Brazil (FATEC-SP). To prevent problems associated with the translocation of fine grains, quartz grains $88-180 \mu \mathrm{m}$ in diameter were obtained after chemical treatments with $20 \%$ HF for 45 $\min , 20 \% \mathrm{HCl}$ for 2 hours, and heavy liquid (SPT) separation. OSL measurements with infrared excitation were performed on the samples in the absence of feldspar crystals. TL and OSL shine-down curves were obtained with a Daybreak Nuclear and Medical Systems Incorporated, Model 1100-Series Automated TL/OSL System. Quartz crystals were stimulated with green light emitted by a Xe-lamp and filtered with an optical filter. A Hoya U-340 (290-370 nm) optical filter was used for detection of the OSL. All of the $\gamma$-irradiation was performed with a ${ }^{60} \mathrm{Co}$ source, and, for bleaching experiments, the samples were submitted directly to sunlight for 16 hours. Natural radioactive isotope contents in the samples were determined with gamma spectroscopy using an Inspector Portable Spectroscopy Workstation, lead shield model 727, and a Canberra $802 \mathrm{NaI}(\mathrm{Tl})$ detector.

Paleodose values were obtained using the total regeneration method and multi-aliquot protocols (Aitken 1998). In this technique, one limitation is the frequent occurrence of high levels of scatter with the growth curves. This occurs because of variations in the mass and other properties from aliquot to aliquot. Therefore, the Natural Normalization (NN) method was used in order to correct the OSL sensitivity variations of the grains and to avoid significant age underestimation (Stokes 1999). In some samples, paleodose values were obtained using the Single Aliquot Regeneration (SAR) method, which uses repeated measurements on a single sample (Lang et al. 1998). Using these concentrations and Bell's equations (Aitken 1998), we determined the annual dose-rate of each sample, which is also listed in Tables I and II. 
TABLE I

Sample numbers, natural radioactivity, paleodoses (P), annual doses (AD), and ages by luminescence for samples from colluvial deposits. Green and blue stimulation were used for OSL measurements. (*OSL SAR).

\begin{tabular}{|c|c|c|c|c|c|c|c|c|c|}
\hline $\begin{array}{c}\text { Sample } \\
\text { ID }\end{array}$ & $\begin{array}{l}\text { Depth } \\
(\mathrm{m})\end{array}$ & $\begin{array}{c}{ }^{235} \mathrm{U}+{ }^{238} \mathrm{U} \\
(\mathrm{ppm})\end{array}$ & $\begin{array}{l}{ }^{232} \mathrm{Th} \\
(\mathrm{ppm})\end{array}$ & $\begin{array}{l}{ }^{40} \mathrm{~K} \\
(\%)\end{array}$ & $\begin{array}{c}\mathrm{AD} \\
(\mu \mathrm{Gy} / \mathrm{yr})\end{array}$ & $\begin{array}{l}\text { P-TL } \\
(\mathrm{Gy})\end{array}$ & $\begin{array}{c}\text { P-OSL } \\
\text { (Gy) }\end{array}$ & $\begin{array}{c}\text { TL Age } \\
(\mathrm{ky})\end{array}$ & $\begin{array}{c}\text { OSL Age } \\
(\mathrm{ky})\end{array}$ \\
\hline 5 & 1.50 & $1.519 \pm 0.038$ & $2.20 \pm 0.065$ & $0.034 \pm 0.003$ & $943 \pm 22$ & 46.10 & 42.50 & $48.8 \pm 6$ & $45 \pm 5.5$ \\
\hline 6 & 3.00 & $1.152 \pm 0.029$ & $0.309 \pm 0.009$ & $0 \pm 0$ & $593 \pm 10$ & 14.50 & 18.81 & $24.5 \pm 2.8$ & $31.7 \pm 3.7$ \\
\hline \multirow[t]{2}{*}{10} & 3.00 & $1.137 \pm 0.028$ & $2.063 \pm 0.061$ & $0.031 \pm 0.003$ & $755 \pm 17$ & 48.90 & 42.18 & $64.7 \pm 7.9$ & $55.8 \pm 6.8$ \\
\hline & 8.00 & $1.218 \pm 0.003$ & $1.899 \pm 0.056$ & $0.036 \pm 0.003$ & $800 \pm 19$ & 104.00 & 97.9 & $130 \pm 16$ & $122 \pm 15$ \\
\hline 13 & 4.00 & $1.013 \pm 0.025$ & $0.551 \pm 0.016$ & $0 \pm 0$ & $663 \pm 12$ & 64.70 & 62.0 & $97.5 \pm 11.5$ & $93.4 \pm 11$ \\
\hline \multirow[t]{3}{*}{14} & 1.00 & $0.739 \pm 0.018$ & $0.659 \pm 0.019$ & $0 \pm 0$ & $531 \pm 9$ & 16.20 & 18.13 & $30.5 \pm 3.5$ & $34 \pm 4$ \\
\hline & 6.50 & $1.112 \pm 0.028$ & $0.710 \pm 0.021$ & $0.071 \pm 0.007$ & $785 \pm 21$ & 51.35 & 52.68 & $65.4 \pm 8.3$ & $67 \pm 8.5$ \\
\hline & 16.50 & $0.675 \pm 0.017$ & $0.406 \pm 0.012$ & $0 \pm 0$ & $500 \pm 9$ & 79.40 & 82.39 & $158 \pm 18.5$ & $164 \pm 19$ \\
\hline 16 & 2.00 & $0.598 \pm 0.016$ & $0.502 \pm 0.015$ & $0 \pm 0$ & $463 \pm 8$ & 13.25 & 15.49 & $28.6 \pm 3.3$ & $33.4 \pm 3.9$ \\
\hline 18 & 3.00 & $1.124 \pm 0.029$ & $3.371 \pm 0.087$ & $0 \pm 0$ & $717 \pm 14$ & 32 & 69 & $44.6 \pm 5.1$ & $96.2 \pm 11.1$ \\
\hline 19 & 5.00 & $0.582 \pm 0.015$ & $1.747 \pm 0.045$ & $0.022 \pm 0.002$ & $478 \pm 14$ & 55 & 33 & $115 \pm 13.2$ & $69 \pm 7.9$ \\
\hline 20 & 9.00 & $0.691 \pm 0.018$ & $2.071 \pm 0.053$ & $0 \pm 0$ & $508 \pm 9$ & 140 & 343 & $275.6 \pm 31.7$ & $675.2 \pm 77.7$ \\
\hline 21 & 1.00 & $1.703 \pm 0.044$ & $5.107 \pm 0.133$ & $0.014 \pm 0.001$ & $1010 \pm 23$ & 166 & 198 & $109.4 \pm 12.6$ & $130.4 \pm 15$ \\
\hline 28 & 3.00 & $1.216 \pm 0.032$ & $3.648 \pm 0.097$ & $0 \pm 0$ & $761 \pm 16$ & 14 & 18 & $18.4 \pm 2.1$ & $23.7 \pm 2.7$ \\
\hline 30 & 2.00 & $0.588 \pm 0.016$ & $1.763 \pm 0.047$ & $0 \pm 0$ & $458 \pm 8$ & 36 & 42 & $78.6 \pm 9$ & $91.7 \pm 10.5$ \\
\hline \multirow[t]{2}{*}{36} & 1.00 & $0.665 \pm 0.016$ & $1.995 \pm 0.049$ & $0 \pm 0$ & $495 \pm 8$ & 22 & 18 & $44.4 \pm 5.1$ & $36.4 \pm 4.2$ \\
\hline & 6.50 & $0.557 \pm 0.014$ & $1.672 \pm 0.042$ & $0 \pm 0$ & $443 \pm 7$ & 149 & 192 & $336.3 \pm 38.7$ & $433.4 \pm 49.8$ \\
\hline \multirow[t]{2}{*}{40} & 1.00 & $1.158 \pm 0.029$ & $3.474 \pm 0.024$ & $0.0177 \pm 0.0018$ & $752 \pm 11$ & 8.20 & 6.9 & $10.9 \pm 1.2$ & $9 \pm 1$ \\
\hline & 6.00 & $0.564 \pm 0.014$ & $1.692 \pm 0.008$ & $0.0526 \pm 0.0054$ & $501 \pm 10$ & 60.30 & 57.19 & $120 \pm 14$ & $114 \pm 13.5$ \\
\hline 44 & 1.00 & $0.781 \pm 0.021$ & $2.343 \pm 0.011$ & $0 \pm 0$ & $551 \pm 6$ & 14.72 & 12.02 & $26.7 \pm 2.9$ & $21.8 \pm 2.4$ \\
\hline 45 & 2.00 & $0.593 \pm 0.015$ & $1.779 \pm 0.005$ & $0 \pm 0$ & $461 \pm 4$ & 10.85 & 9.78 & $23.5 \pm 2.5$ & $21.2 \pm 2.3$ \\
\hline 48 & 3.00 & $1.336 \pm 0.033$ & $4.008 \pm 0.043$ & $0.0424 \pm 0.0043$ & $863 \pm 16$ & 26.0 & 29.14 & $30 \pm 3.5$ & $33.7 \pm 4$ \\
\hline 52 & 3.00 & $0.735 \pm 0.018$ & $2.205 \pm 0.032$ & $0 \pm 0$ & $529 \pm 7$ & 17.48 & 15.95 & $33 \pm 3.7$ & $37.7 \pm 4.2$ \\
\hline 58 & 5.00 & $0.784 \pm 0.020$ & $2.352 \pm 0.028$ & $0.0439 \pm 0.0045$ & $598 \pm 12$ & 32.17 & 35.76 & $53.7 \pm 6.4$ & $59.8 \pm 7$ \\
\hline 61 & 4.00 & $1.470 \pm 0.037$ & $4.41 \pm 0.04$ & $0 \pm 0$ & $884 \pm 13$ & 24.98 & 23.02 & $28.2 \pm 3.2$ & $26 \pm 2.9$ \\
\hline 62 & 3.00 & $1.018 \pm 0.026$ & $3.054 \pm 0.078$ & $0 \pm 0$ & $666 \pm 13$ & 20.15 & 21.93 & $30.2 \pm 3.6$ & $33 \pm 4$ \\
\hline 68 & 3.00 & $0.707 \pm 0.018$ & $2.121 \pm 0.054$ & $0 \pm 0$ & $516 \pm 9$ & 9.55 & 9.05 & $18.5 \pm 2$ & $17.5 \pm 2$ \\
\hline 69 & 3.00 & $1.123 \pm 0.027$ & $3.370 \pm 0.083$ & $0 \pm 0$ & $717 \pm 13$ & 39.75 & 35.94 & $55.4 \pm 6.5$ & $50 \pm 6$ \\
\hline 72 & 3.00 & $1.352 \pm 0.034$ & $4.055 \pm 0.051$ & $0 \pm 0$ & $827 \pm 16$ & 33 & 25 & $39.9 \pm 4.6$ & $30.2 \pm 3.5$ \\
\hline 74 & 3.00 & $1.391 \pm 0.037$ & $4.172 \pm 0.054$ & $0 \pm 0$ & $674 \pm 12$ & 117 & 169 & $173.6 \pm 20$ & $250.7 \pm 28.8$ \\
\hline 76 & 2.00 & $0.941 \pm 0.024$ & $2.822 \pm 0.012$ & $0 \pm 0$ & $846 \pm 18$ & 59 & 106 & $69.7 \pm 8$ & $125.3 \pm 14.4$ \\
\hline 80 & 3.50 & $0.571 \pm 0.015$ & $1.714 \pm 0.021$ & $0.096 \pm 0.010$ & $628 \pm 12$ & 25 & 26 & $39.6 \pm 4.6$ & $41.2 \pm 4.7$ \\
\hline 85 & 3.00 & $0.424 \pm 0.011$ & $1.273 \pm 0.003$ & $0 \pm 0$ & $548 \pm 18$ & 62 & 60 & $113.1 \pm 13$ & $109.5 \pm 12.6$ \\
\hline 89 & 2.00 & $0.616 \pm 0.017$ & $1.848 \pm 0.012$ & $0 \pm 0$ & $379 \pm 5$ & 21 & 11 & $55.4 \pm 6.4$ & $29 \pm 3.3$ \\
\hline 91 & 4.00 & $0.502 \pm 0.013$ & $1.506 \pm 0.02$ & $0.023 \pm 0.002$ & $472 \pm 8$ & 82 & 186 & $173.7 \pm 20$ & $394.1 \pm 45.3$ \\
\hline 95 & 3.50 & $0.577 \pm 0.015$ & $1.732 \pm 0.054$ & $0 \pm 0$ & $440 \pm 9$ & 25 & 43 & $56.8 \pm 6.5$ & $97.7 \pm 11.2$ \\
\hline 98 & 3.50 & $0.82 \pm 0.02$ & $2.46 \pm 0.05$ & $0.059 \pm 0.006$ & $475 \pm 9$ & 11 & 10 & $23.2 \pm 2.7$ & $21.1 \pm 2.4$ \\
\hline 100 & 2.00 & $0.60 \pm 0.01$ & $1.82 \pm 0.04$ & $0 \pm 0$ & $453 \pm 7$ & 29 & 24 & $64 \pm 7.4$ & $53 \pm 6.1$ \\
\hline 104 & 6.00 & $0.68 \pm 0.01$ & $2.06 \pm 0.05$ & $0.009 \pm 0.0009$ & $467 \pm 7$ & 12.74 & 13.76 & $27 \pm 3$ & $29 \pm 3.5$ \\
\hline 105 & 2.00 & $2.17 \pm 0.05$ & $6.53 \pm 0.17$ & $0.013 \pm 0.0013$ & $517 \pm 10$ & 101.4 & 105 & $196 \pm 22$ & $203 \pm 24$ \\
\hline 111 & 1.50 & $1.35 \pm 0.03$ & $4.07 \pm 0.09$ & $0.004 \pm 0.004$ & $1.420 \pm 29$ & 95.37 & 91.4 & $76.8 \pm 9.5$ & $73.6 \pm 9$ \\
\hline 112 & 7.00 & $0.98 \pm 0.02$ & $2.94 \pm 0.07$ & $0.010 \pm 0.001$ & $591 \pm 11$ & 13.2 & 21.8 & $22.3 \pm 2.5$ & $36.3 \pm 4.3$ \\
\hline 114 & 3.50 & $0.75 \pm 0.01$ & $2.27 \pm 0.05$ & $0 \pm 0$ & $660 \pm 13$ & 31.0 & 41.0 & $46.9 \pm 5.6$ & $46.9 \pm 5.6$ \\
\hline 115 & 4.00 & $0.59 \pm 0.01$ & $1.77 \pm 0.04$ & $0.032 \pm 0.003$ & $716 \pm 13$ & 28.20 & 39 & $39.2 \pm 4.5$ & $54.2 \pm 6.4$ \\
\hline 118 & 4.00 & $0.89 \pm 0.02$ & $2.68 \pm 0.06$ & $0.014 \pm 0.001$ & $541 \pm 9$ & 13.36 & 13.71 & $24.7 \pm 2.8$ & $25 \pm 3$ \\
\hline 120 & 3.50 & $1.15 \pm 0.02$ & $3.46 \pm 0.008$ & $0 \pm 0$ & $622 \pm 12$ & 10.16 & 12.37 & $16.3 \pm 2$ & $19.5 \pm 2.3$ \\
\hline 121 & 1.00 & $3.2851 \pm 0.0857$ & $1.0950 \pm 0.0286$ & $0 \pm 0$ & $630 \pm 13$ & 24.64 & 21.74 & $39 \pm 4.5$ & $50 \pm 6$ \\
\hline 125 & 4.00 & $2.3492 \pm 0.0631$ & $0.7831 \pm 0.0210$ & $0.0096 \pm 0.0010$ & $885 \pm 17$ & 58 & 247 & $136.7 \pm 15.7$ & $279.1 \pm 32.1$ \\
\hline 127 & 5.00 & $1.1289 \pm 0.0269$ & $0.3763 \pm 0.0089$ & $0.0043 \pm 0.0005$ & $638 \pm 11$ & 14 & 14 & $21.9 \pm 2.5$ & $21.9 \pm 2.5$ \\
\hline 128 & 3.50 & $2.9031 \pm 0.0766$ & $0.9677 \pm 0.0255$ & $0 \pm 0$ & $812 \pm 15$ & 103 & 251 & $126.9 \pm 14.6$ & $309.1 \pm 35.6$ \\
\hline \multirow[t]{2}{*}{ S01 } & 2.00 & $1.06 \pm 0.10$ & $3.89 \pm 0.39$ & $0.0015 \pm 0.002$ & $760 \pm 60$ & 87.4 & 94.83 & $115 \pm 14$ & $124 \pm 15^{*}$ \\
\hline & 12.00 & $0.42 \pm 0.04$ & $0.77 \pm 0.07$ & $0.202 \pm 0.020$ & $550 \pm 40$ & 328.6 & 308.10 & $595 \pm 70$ & $557 \pm 65^{*}$ \\
\hline \multirow[t]{2}{*}{ S02 } & 2.00 & $0.95 \pm 0.09$ & $2.00 \pm 0.20$ & $0.311 \pm 0.031$ & $890 \pm 70$ & 86.2 & 98.26 & $96 \pm 12$ & $110 \pm 14^{*}$ \\
\hline & 10.00 & $0.77 \pm 0.07$ & $2.57 \pm 0.25$ & $0.075 \pm 0.007$ & $645 \pm 45$ & 260.0 & 282.19 & $402 \pm 49$ & $436 \pm 53^{*}$ \\
\hline
\end{tabular}


TABLE II

Sample numbers, natural radioactivity, paleodoses (P), annual doses (AD), and ages by TL and OSL for samples from alluvial deposits.

\begin{tabular}{c|c|c|c|c|c|c|c|c|c}
\hline $\begin{array}{c}\text { Sample } \\
\text { ID }\end{array}$ & $\begin{array}{c}\text { Depth } \\
(\mathrm{m})\end{array}$ & $\begin{array}{c}{ }^{235} \mathrm{U}+{ }^{238} \mathrm{U} \\
(\mathrm{ppm})\end{array}$ & $\begin{array}{c}{ }^{232} \mathrm{Th} \\
(\mathrm{ppm})\end{array}$ & $\begin{array}{c}{ }^{40} \mathrm{~K} \\
(\%)\end{array}$ & $\begin{array}{c}\text { AD } \\
(\mu \mathrm{Gy} / \mathrm{yr})\end{array}$ & $\begin{array}{c}\text { P-TL } \\
(\mathrm{Gy})\end{array}$ & $\begin{array}{c}\text { P-OSL } \\
(\mathrm{Gy})\end{array}$ & $\begin{array}{c}\text { TL Age } \\
(\mathrm{ky})\end{array}$ & $\begin{array}{c}\text { OSL Age } \\
(\mathrm{ky})\end{array}$ \\
\hline 9 & 1.70 & $0.565 \pm 0.013$ & $0.455 \pm 0.013$ & $0 \pm 0$ & $446 \pm 7$ & 16.2 & 14.5 & $36 \pm 4.1$ & $32 \pm 3.7$ \\
15 & 1.00 & $1.571 \pm 0.041$ & $2.469 \pm 0.073$ & $0 \pm 0$ & $933 \pm 20$ & 18.6 & 24.00 & $20 \pm 2.4$ & $25 \pm 3$ \\
24 & 1.00 & $0.796 \pm 0.019$ & $2.386 \pm 0.057$ & $0 \pm 0$ & $558 \pm 9$ & 46 & 49 & $82.4 \pm 9.5$ & $87.8 \pm 10.1$ \\
& 9.00 & $0.462 \pm 0.001$ & $0.252 \pm 0.007$ & $0 \pm 0$ & $397 \pm 6$ & 15.3 & 13.5 & $38.5 \pm 4.4$ & $34 \pm 3.9$ \\
96 & 9.00 & $1.41 \pm 0.36$ & $4.25 \pm 0.11$ & $0 \pm 0$ & $859 \pm 18$ & 88.64 & 88.43 & $103 \pm 12.5$ & $102 \pm 12.5$ \\
99 & 6.00 & $0.47 \pm 0.01$ & $1.41 \pm 0.03$ & $0.221 \pm 0.002$ & $424 \pm 8$ & 49.65 & 71.40 & $155 \pm 18$ & $168 \pm 20$ \\
103 & 1.50 & $0.79 \pm 0.02$ & $2.37 \pm 0.06$ & $0 \pm 0$ & $556 \pm 10$ & 48.50 & 50.40 & $87 \pm 10$ & $90.5 \pm 10$ \\
108 & 1.00 & $0.35 \pm 0.008$ & $1.05 \pm 0.026$ & $0.007 \pm 0.0008$ & $352 \pm 5$ & 9.59 & 9.11 & $27.2 \pm 3.1$ & $25.8 \pm 3$ \\
117 & 4.00 & $0.43 \pm 0.01$ & $1.31 \pm 0.03$ & $0 \pm 0$ & $386 \pm 5$ & 18.78 & 19.34 & $48.5 \pm 5$ & $50 \pm 5.7$ \\
\hline
\end{tabular}

The cosmic ray contribution was virtually calculated for the study area (Engenheiro Sérgio Motta Dam at Porto Primavera), and a value of $174.22 \mu \mathrm{Gy} / \mathrm{yr}$ was found (Sallun et al. 2007c) using the Prescott and Stephan (1982) protocol.

The regional analysis of the chronological data was done by graphical methods. For this, the ages obtained by luminescence of the colluvial sediments were considered according to the age distribution frequencies in the Gaussian curve. The occurrence probabilities were calculated for every 5,000 year interval, and Gaussian curves were generated, in addition to the age curves representative of the maximum and minimum ages obtained by luminescence. The curves were equally spaced at 50,000 year intervals, and the standard deviation for each curve was adjusted at $10 \%$.

\section{RESULTS}

In this study, Quaternary ages were obtained for the colluvial and alluvial deposits (Tables I and II), as in Tatumi et al. (2006). The natural radioactive content of the colluvium and alluvium samples are shown in Tables I and II. The data indicate that ${ }^{40} \mathrm{~K}$ contents were almost zero. We also did not observe the presence of feldspar crystals, which may explain the very low concentration of ${ }^{40} \mathrm{~K}$ in the samples.

The comparison of ages obtained by luminescence (with the respective errors) in the colluvial deposits and the $\delta^{18} \mathrm{O}(\%)$ global change curve of sunlight intensities according to equinoxial precession, ecliptical obliquity, terrestrial orbit eccentricity, and geomagnetic polarity (Berger 1989) are shown in Figure 3. The greater concentration of ages occurs between 6,000 to 220,000 years B.P., which includes the period from the Illinoian Glaciation, passing through the Sangamon Interglacial, until the end of the Wisconsin Glaciation. There is a gap in the record between 675,000 and 850,000 years B.P. The ages of the colluvial deposits were also compared with the $\delta^{13} \mathrm{C}(\% 0)$ data obtained from speleothems of the Botuverá Cave in southern Brazil, which were studied by Cruz Jr. et al. (2005). The record did not allow any correlation with the $\delta^{13} \mathrm{C}(\%)$ changes that are indicative of paleotemperature oscillations measured by those authors (Fig. 3).

The comparison between the ages obtained by luminescence, with the respective errors, of the Paraná Alloformation alluvial deposits and the global changes of oxygen isotope ratios $\delta^{18} \mathrm{O}(\%)$, insolation, precession, obliquity, eccentricity, and geomagnetic polarity are shown in Figure 4. The greater concentration of ages is between 15,000 to 50,000 years B.P., which corresponds to the middle to upper Pleniglacial of the Wisconsinian glaciation, that is, the last North-American glaciation. The same ages of the Paraná Alloformation, until 120,000 years B.P., were also compared with the $\delta^{13} \mathrm{C}$ (\%) obtained data from the Botuverá cave (Cruz Jr. et al. 2005), but they did not correlate them with the $\delta^{13} \mathrm{C}$ $(\%)$ changes that are indicative of paleotemperature oscillations (Fig. 4).

\section{DISCUSSION}

Lang and Hönscheidt (1999) and Heimsath et al. (2002) confirmed that reworking is an important factor in colluviation, and the ages of the sediments can only be con- 


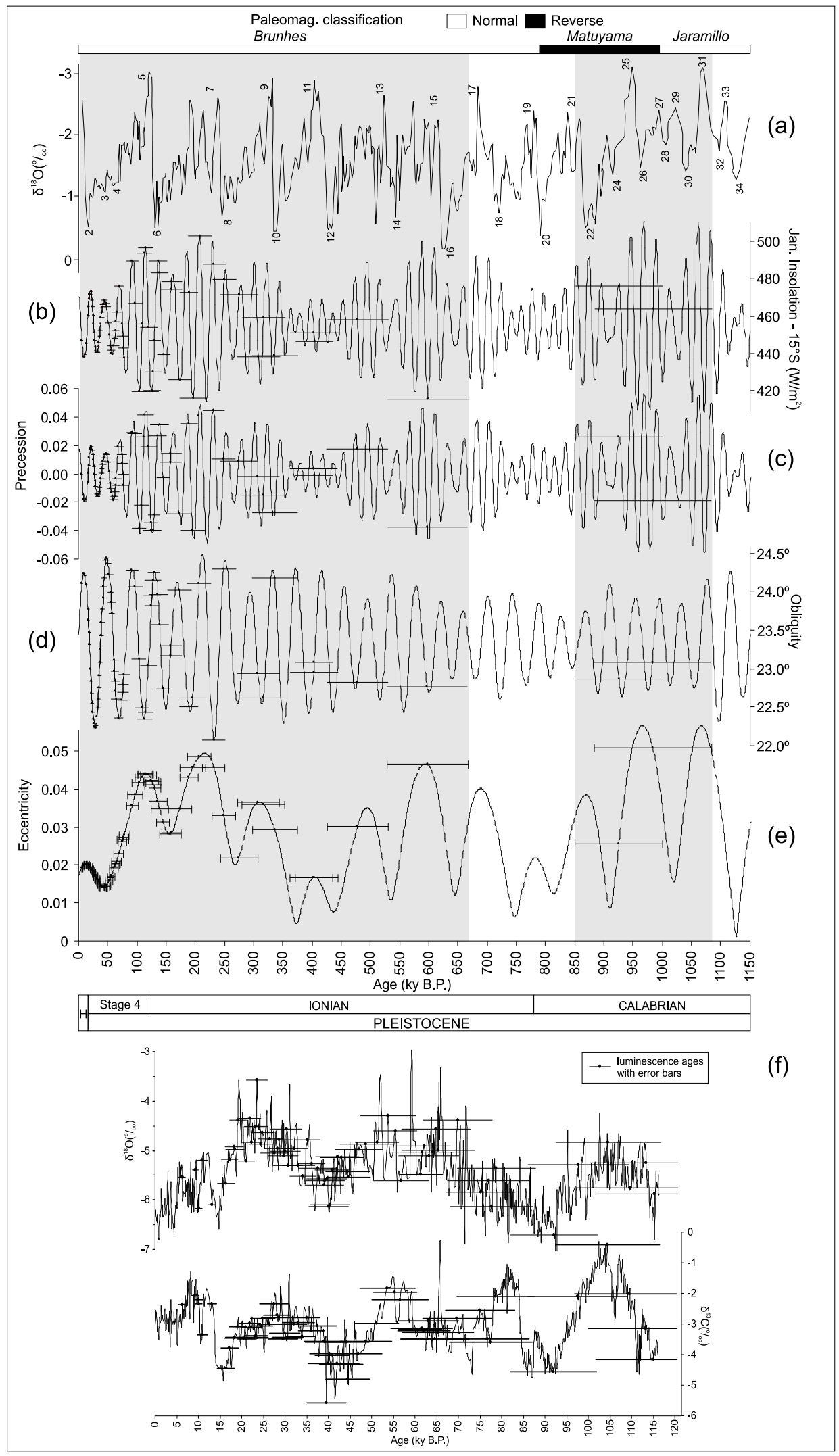


Fig. 3 - Comparison between the ages obtained by TL-OSL methods (in $\times 10^{3}$ years B.P.) and the respective analytical errors in the Paranavai Alloformation colluvial deposits (circles with error bars) plotted with the same ages of several paleoclimatic proxy records: (a) $\delta^{18} \mathrm{O} \% 0$ change curves obtained from the compositional data of deepsea cores of the Pacific Ocean (Petit et al. 1999) - cores V19-30 (3S/83W - Shackleton and Pisias 1985), ODP-677 ( $1^{\circ} 12^{\prime} \mathrm{N} / 83^{\circ} 44^{\prime} \mathrm{W}$ - Shackleton et al. 1990) and ODP-846 ( $3^{\circ} 05^{\prime} 42^{\prime \prime} \mathrm{S} / 90^{\circ} 49^{\prime} 06^{\prime \prime} \mathrm{W}$ - Shackleton et al. 1995) with indicators in numbers of glacial (below) and interglacial (above) stades based on Bassinot et al. (1994); (b) January insolation at $15^{\circ} 00^{\prime} \mathrm{S}$ in W/m² (Berger and Loutre 1991); (c) Equinoxial precession during the perihelium, when the Earth is nearest the Sun (Berger 1992); (d) Ecliptical obliquity (Berger 1992); (e) Terrestrial orbit eccentricity (Berger 1992); (f) isotopic curves $\left(\delta^{13} \mathrm{C}\right.$ and $\delta^{18} \mathrm{O}$ ) obtained from the Botuverá Cave (Cruz Jr. et al. 2005) in the Southern Brazil $\left(27^{\circ} 13^{\prime} 24^{\prime \prime} \mathrm{S} / 49^{\circ} 09^{\prime} 20^{\prime \prime} \mathrm{W}\right)$. Quaternary geologic time scale is in accordance with Ogg and Pillans (2008) (H: Holocene), and the geomagnetic polarity calibration time scale was taken from oceanographic data by S.J. Crowhurst (Delphi Project 2002 - http://www.esc.cam.ac.uk/delphi/) and modified from Funnel (1996). Ages in x10³ B.P., with origin 0 in year 1950 A.C.

sidered by neglecting the deposited volumes. Therefore, the ages can represent the main or secondary colluviation episodes, but they do not distinguish them.

The obtained ages are shown in cumulative probability curves, wich are represented by Gaussian distributions generated from the ages and analytical errors of the colluvial deposits. The ages clearly indicate more intensive colluviation phases, and the better preservation of deposits for the last $135 \mathrm{ky}$ record, probably associated with paleoclimatic fluctuations that occurred among the oxygen isotope curve shown in Figure 5A. The $\delta^{18} \mathrm{O}(\%)$ isotope stage curves show correlations among inferred events of colluvial aggradation represented by the ages of the probability peaks. The diagram shows aggradational events, with most of luminescence ages situated on two probability peaks, between about 13,000 to 64,000 years and 125,000 to 135,000 years B.P. It is remarkable that the age records from $1,100,000$ to 135,000 years are rare, erroneously suggesting that a lower frequency of colluvial processes has occurred. The considerable thicknesses of older deposits suggest that a reworking of the older colluvial deposits, aggradation and degradation events, toward younger cycles, probably occurred at ages less than 135,000 years B.P. There is a dominance of colluvial deposits with ages between 13,000 to 64,000 years B.P., possibly because the "zeroing" during the subsequent period was insufficient. The absence of deposits with ages between 675,000 and 850,000 years B.P. could indicate a period of paleoclimatic and paleotectonic quietness or a subsequent strong reworking, which could have removed the colluviation records of that time interval.
The luminescence ages of the Paranavaí Alloformation deposits suggest multiple episodes of aggradation during glacial-interglacial transitions. It could not occur as an unique pulse sediment arrival in the glacial-interglacial transition, but as a series of aggradation events at the millennial scale, represented by several deposits approximately correlatable with the identified oxygen isotope stages. We recognized at least two more important colluvial aggradation episodes, approximately in the transitions between isotope stages 2-3-4 and 5-6.

The colluvial aggradation episodes could have occurred during rapid climatic changes, detached from colder and drier stades, but the colluviation episodes were probably more likely related to glacial-interglacial transitions. A possible cause for accelerated slope erosion during periods of paleoclimatic change could be related to a reduction in the vegetal cover due to a rapid warming, as in the models suggested by Wells et al. (1987) and Bull (1991) that are better applied at millennial than glacial-interglacial time scales.

Neoctonic activity was recognized in the Upstream Paraná River right margin by Fortes et al. (2005), beside geomorphological evidence suggesting that the UPRHB is controlled by tectonics that originated higher fluvial terraces along the left margin than in the right margin (Suguio et al. 1984, Fúlfaro and Perinotto 1994, Riccomini 1997, Sallun et al. 2007a). These paleoclimatic and neotectonic (uplift and/or subsidence) activities could have caused changes in baselevel, with consequent reshaping of the relief.

These data are corroborated by UPRHB geomorphological analysis (Sallun et al. 2007a), in wich the 


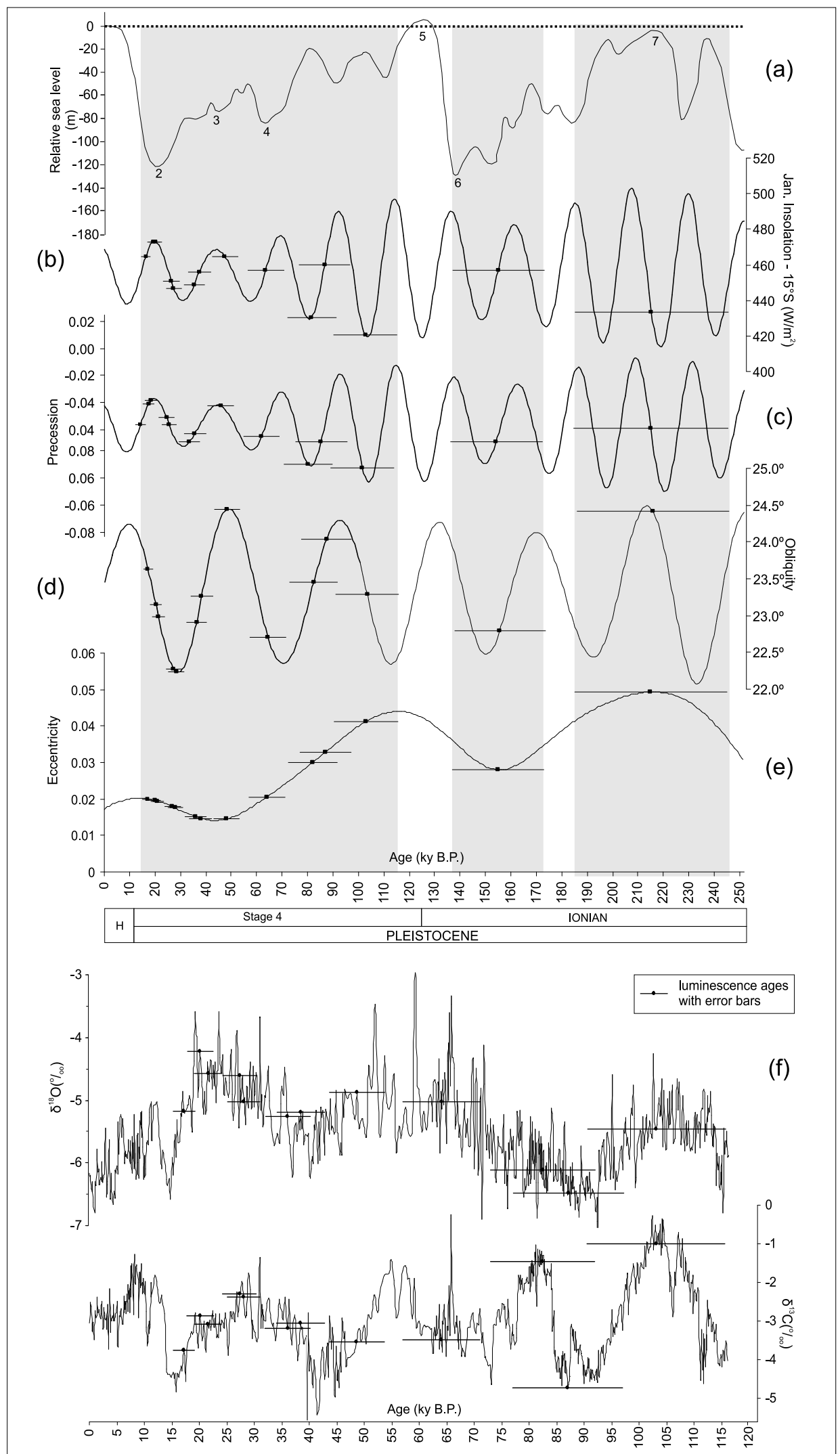


Fig. 4 - Comparison between the ages obtained by TL-OSL methods (in $\times 10^{3}$ years B.P.) and the respective analytical errors in the Paraná Alloformation alluvial deposits (circles with error bars) plotted with the same ages of several paleoclimatic proxy records: (a) sealevel change curve with indicators in numbers of glacial (below) and interglacial (above) stades, based on Bassinot et al. (1994); (b) January insolation at $15^{\circ} 00^{\prime} \mathrm{S}$ in W/m² (Berger and Loutre 1991); (c) Equinoxial precession during the perihelium, when the Earth is nearest the Sun (Berger 1992); (d) Ecliptical obliquity (Berger 1992); (e) Terrestrial orbit eccentricity (Berger 1992); (f) isotopic curves ( $\delta^{13} \mathrm{C}$ and $\left.\delta^{18} \mathrm{O}\right)$ obtained from the Botuverá Cave (Cruz Jr. et al. 2005) in the Southern Brazil $\left(27^{\circ} 13^{\prime} 24^{\prime \prime} \mathrm{S} / 49^{\circ} 09^{\prime} 20^{\prime \prime} \mathrm{W}\right)$. Quaternary geologic time scale is in accordance with Ogg and Pillans (2008) (H: Holocene), and the geomagnetic polarity calibration in time scale was taken from oceanographic data by S.J. Crowhurst (Delphi Project 2002 - http://www.esc.cam.ac.uk/delphi/) and modified from Funnel (1996). Ages in x10 3 B.P. with the 0 origin in year 1950 A.C.

distribution of the Paranavaí Alloformation colluvial deposits suggests that these sediments were deposited on peneplain surfaces re-shaped during the Pleistocene, which were previously recognized by Bigarella and Andrade (1965) and O.J. Justus (1985, unpublished data). The South-American Surface (King 1956, 1967), developed at the Late Cretaceous-Paleogene transition (Riccomini et al. 2004), were correctable with $\mathrm{Pd}_{3}$ pediplain (Bigarella and Andrade 1965).

After the identification of the antiquity relationships between the geomorphological surfaces (Sallun et al. 2007a), and absolute dating of the sedimentary deposits, the relative ages of these surfaces were immediately established. Geomorphological and sedimentological analyses of the Alto Rio Paraná Allogroup, in addition to their age distributions, allowed the recognition of a probable sequence of degradational and aggradational surfaces in the following order: $\mathrm{Pd}_{3}$ pediplain in the Late Cretaceous-Paleogene, $\mathrm{Pd}_{2}$ pediplain between $1,000,000$ and 120,000 years, $\mathrm{Pd}_{1}$ pediplain between 120,000 and 10,000 years, and $\mathrm{Pd}_{0}$ pediplain between 10,000 years and today (Fig. 5B).

\section{CONCLUSIONS}

Previous studies have suggested that paleoclimatic changes could represent an important factor for the extensive and intensive colluviation that occurred within the UPRHB because geochronological data were completely absent. The Paranavaí Alloformation colluvial deposits were here interpreted as recording colluviation episodes whose ages were measured by luminescence methods (TL and OSL). The obtained ages suggest that the colluviation episodes could probably have been more frequent during paleoclimatic transitions, approximately between isotope stages 2-3-4 and 5-6. Though temperature and vegetal cover reductions can be used to justify the occurrence of several colluviation events, it is probable that brief periods of heavier precipitation also occurred during paleoclimatic transitions, which could explain the extensively occurrence of UPRHB colluvial deposits. Moreover, the intermittent colluviation record across the entire hydrographic basin suggests a constant arrival of sediments during the Quaternary, in addition to a probable neotectonic activity.

\section{ACKNOWLEDGMENTS}

First of all, we thank Fundação de Amparo à Pesquisa do Estado de São Paulo (FAPESP) for scholarships and research grant to Alethéa E.M. Sallun (Processes 03/ 01737-5 and 08/03818-6), and Conselho Nacional de Desenvolvimento Científico e Tecnológico (CNPq) for a research productivity scholarship to Kenitiro Suguio (Process 307018/2003-3).

\section{RESUMO}

Depósitos coluviais ocorrem extensivamente na Bacia Hidrográfica do Alto Rio Paraná, no sudeste, sul e centro-oeste do Brasil. Esses depósitos foram reconhecidos como uma unidade aloestratigráfica, e são interpretados como depósitos formados por processos de rastejo durante o Quaternário. Cada perfil coluvial estudado é muito homogêneo, e indica relativamente períodos longos de estabilidade da paisagem, suficiente para desenvolvimento de espessa cobertura. Estes depósitos foram datados por luminescência para estabelecer cronologicamente períodos de deposição coluvial mais intensa entre 6 e 220 ky B.P. Estes eventos correspondem aproximadamente às transições entre os estágios de isótopos do oxigênio 2-3-4 e 5-6, sugerindo que essa agradação esteve influenciada por 


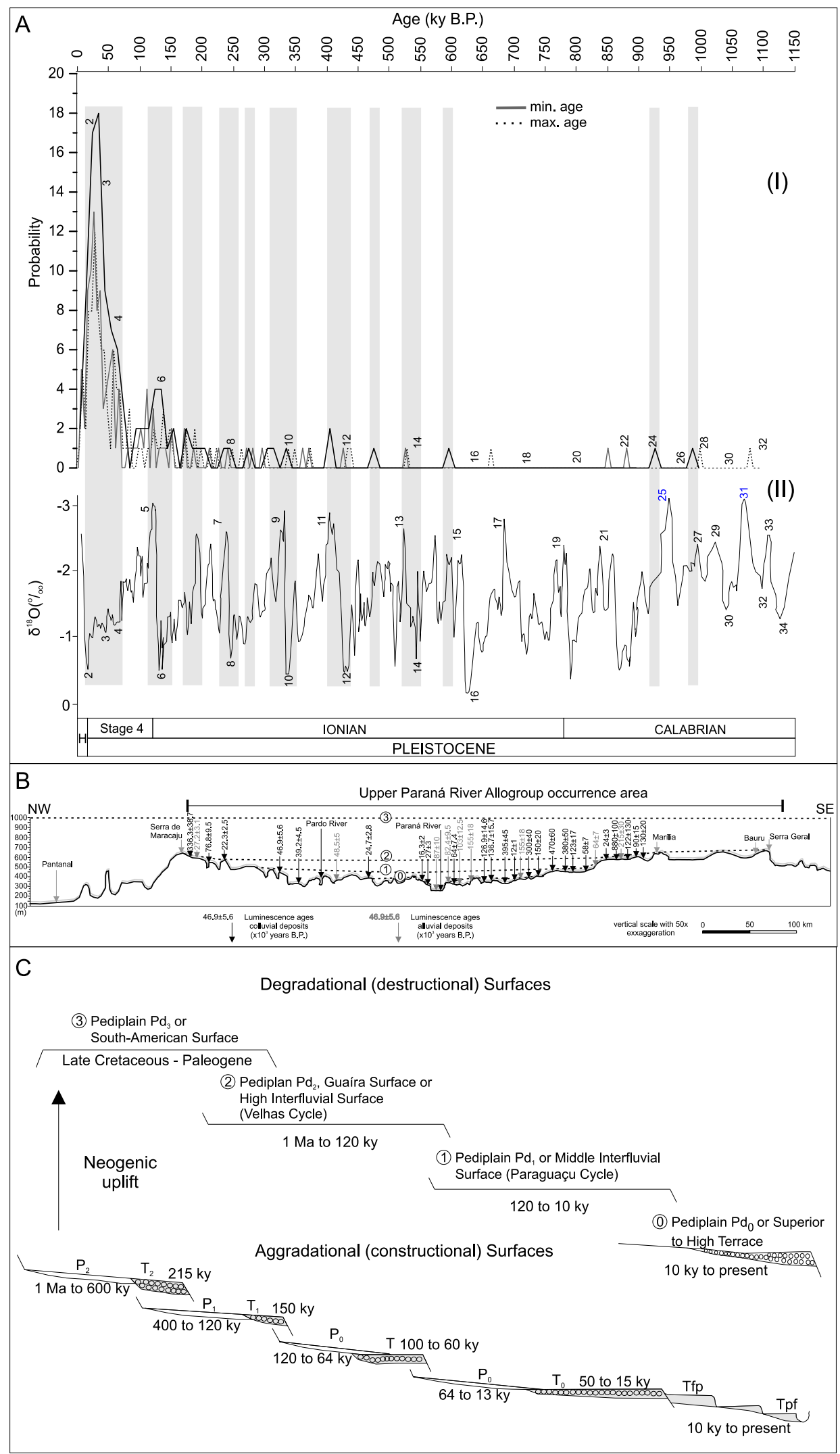

Fig. 5 
mudanças climáticas. Desenvolvimento aluvionar foi correlacionado ao Peniglacial médio a superior da Glaciação Wisconsiana. Os períodos de intensidade ou frequência maior de precipitação que ocorre durante as transições climáticas estão provavelmente correlacionados com os eventos de agradação. A regularidade do registro coluvionar sugere constante soerguimento acompanhado de deposição sedimentar por toda UPRHB devido à atividade neotectônica durante o último milhão de anos.

Palavras-chave: coluviação, aluviação, Quaternário, datação luminescente, Brasil.

\section{REFERENCES}

AITKEN MJ. 1998. An introduction to optical dating. London: Oxford University Press, 230 p.

AlmeidA FFM DE. 1983. Aspectos gerais da geologia da bacia do alto Paraná. In: Simpósio Sobre a GeotecNiA DA BACIA Do Alto PARAnÁ, 1. São Paulo, Brasil. Anais do XXIX Congresso Brasileiro de Espeleologia, São Paulo, SP, Brasil, ABGE, p. 9-16.

BARTHELnESS H. 1960. Comentário geomorfológico sobre o vale do Rio Ivaí. UPCP/BPG 1: 8-17.

BASSINot FC, LABEyRIE LD, VinCENT E, QUidELlEUR X, Shackleton NJ And Lancelot Y. 1994. The astronomical theory of climate and the age of the BrunhesMatuyama magnetic reversal. Earth Planet Sc Lett 126: 91-108.

BERGER A. 1989. Pleistocene climatic variability at astronomical frequencies. Quaternary Int 2: 1-14.

BERGER A. 1992. Orbital Variations and Insolation Database. IGBP PAGES/World Data Center-A for Paleoclimatology Data Contribution Series \#92-007. NOAA/NGDC. USA: Paleoclimatology Program, Boulder CO.

Berger A AND Loutre MF. 1991. Insolation values for the climate of the last 10 million years. Quaternary Sci Rev 10(4): 297-317.

Bigarella JJ AND ANDrade GO. 1965. Contribution to the study of the Brazilian Quaternary. In: WRIGHT JR HE AND FREY D (Eds), International Studies on the Quaternary. Geol Soc Spec Pub 84: 443-451.

Bigarella JJ AND MAZUChOWSKI JZ. 1985. Visão integrada da problemática da erosão. In: SIMPÓSIO NACiONAL CONTROLE DA EROSÃO, 2, Livro guia, 332 p.

BROECKER WS. 1965. Isotope geochemistry and Pleistocene climatic record. In: WRIGHT JR HE AND FREY D. (Eds), International Studies on the Quaternary. Geol Soc Spec
Pub 84: 737-753.

BROECKER WS AND VAN DONK J. 1970. Insolation changes, ice volumes and the $\delta^{18} \mathrm{O}$ record of deep-sea cores. Rev Geophys Space Phys 8: 169-197.

Bull WB. 1991. Geomorphic Responses to Climatic Change. New York: Oxford Press, 326 p.

CLARKE ML. 1996. IRSL dating of sands: bleaching characteristics at deposition inferred from the use of single aliquots. Radiat Meas 26: 611-620.

Cruz Jr FW, Burns SJ, Karmann I, Sharp WD, Vuille M, Cardoso aO, Ferrari Ja, Silva dias PL AND VIANA JR O. 2005. Insolation-driven changes in atmospheric circulation over the past 116,000 years in subtropical Brazil. Nature 434: 63-66.

Dias-Brito D, Musacchio EA, Castro JC de, MaraNHÃo MSAS, SUAREZ JM AND Rodrigues R. 2001. Grupo Bauru: uma unidade continental do Cretáceo no Brasil - concepções baseadas em dados micropaleontológicos, isotópicos e estratigráficos. Rev Paleobiol 20: 245-304.

Emiliani C. 1955. Pleistocene temperatures. J Geol 63: $538-578$.

ERIKSSON MG, Olley JM AND Payton RW. 2000. Soil erosion history in central Tanzania based on OSL dating of colluvial and alluvia hillslope deposits. Geomorphology 36: $107-128$.

Fortes E, Stevaux JC AND Volkmer S. 2005. Neotectonics and channel evolution of the Lower Ivinhema River: A right-bank tributary of the upper Paraná River, Brazil. Geomorphology 70: 325-338.

Fúlfaro VJ And Perinotto JAJ. 1994. Geomorfologia do Estado do Mato Grosso do Sul e o Arcabouço Estrutural. In: Congresso Brasileiro de Geologia, 38, Camboriú, Brasil. Boletim de Resumos ExpandiDos, Camboriú: SBG, 1994, p. 197-198.

FUNNEL B. 1996. Global sea-level and the (pen-)insularity of late Cenozoic Britain. In: PreECE RC (Ed), Island Britain: a Quaternary perspective. Geol Soc Spec Pub 96: $3-13$.

Hanson PR, Mason JA And Goble RJ. 2004. Episodic Late Quaternary slopewash deposition as recorded in colluvial aprons, Southeastern Wyoming. Quaternary Sci Rev 23: 1835-1846.

Heimsath AM, Chappell J, Spooner NA AND QuestiAUX DG. 2002. Creeping soil. Geology 30(2): 111-114.

KING LC. 1956. A geomorfologia do Brasil Oriental. Rev Bras Geog 2: 3-48. 
KING LC. 1967. Morphology of the Earth. Edinburgh: Oliver and Boyd, $726 \mathrm{p}$.

KNOX JC. 1972. Valley alluviation in southwestern Wisconsin. Ann Assoc Am Geogr 62: 401-410.

LANG A. 1994. Luminescence dating of Holocene reworked silty sediments. Quaternary Sci Rev 13: 525-528.

LANG A. 2003. Phases of soil erosion-derived colluviation in the loess hills of South Germany. Catena 51: 209-221.

LANG A AND HönscheIdT S. 1999. Age and source of soil erosion-derived colluvial sediments at Vaihingen-Enz, Germany. Catena 38: 89-107.

LANG A AND WAGNER GA. 1996. Infrared stimulated luminescence dating of archaeosediments. Archaeometry 38 : 129-141.

LANG A, Rieser U, Habermann J And Wagner GA. 1998. Luminescence dating of sediments. Naturwissenschaften 85: 515-523.

LEOPOLD M AND VöLKel J. 2007. Colluvium: Definition, differentiation, and possible suitability for reconstructing Holocene climate data. Quaternary Int 162/163: 133-140.

Milankovitch M. 1920. Théorie mathématique des phénomenès thermiques produits par la radiation solaire. Yougoslavia: Academie Yougoslave des Sciences et Arts, $339 \mathrm{p}$.

Murray AS, Olley JM And Caitcheon GC. 1995. Measurement of equivalent doses in quartz from contemporary water-lain sediments using optically stimulated luminescence. Quaternary Sci Rev 14: 365-371.

OGG JG And PILlans B. 2008. Establishing Quaternary as a formal international Period/System. Episodes 31(2): 230-233.

Olley JM, Caitcheon G And Murray AS. 1998. The distribution of apparent dose as determined by Optically Stimulated Luminescence in small aliquots of fluvial quartz: implication for dating young sediments. Quaternary Geochronol 17: 1033-1040.

Petit JR ET AL. 1999. Climate and atmospheric history of the past 420,000 years from the Vostok ice core, Antarctica. Nature 399: 429-436.

PRESCOTT JR AND STEPHAN LG. 1982. The contribution of cosmic radiation to the environmental dose for thermoluminescent dating, latitude, altitude and depth dependences. PACT 6: 17-25.

Renne P, Ernesto M, Pacca IG, Coe RS, Glen JM, PrÉvot M AND PERrin M. 1992. The age of Paraná Flood Volcanism, rifting of Gondwanaland, and the Jurassic-Cretaceous boundary. Science 258: 975-979.
RiCCOMINi C. 1997. Arcabouço estrutural e aspectos do tectonismo gerador e deformador da Bacia Bauru no Estado de São Paulo. Rev Bras Geoc 27(2): 153-162.

Riccomini C, SANT'AnNA LG AND Ferrari AL. 2004. Evolução geológica do Rift Continental do Sudeste do Brasil. In: Mantesso Neto V et AL. (Eds), Geologia do continente Sul-americano: evolução da obra de Fernando Flávio Marques de Almeida. BECA: São Paulo, SP, Brasil, p. 385-405.

SAllun AEM And Suguio K. 2008. Sedimentological characterization of the quaternary deposits in the region between Marília and Presidente Prudente, São Paulo State, Brazil. Rev Esc Min 61: 343-356.

Sallun AEM, Suguio K And Sallun Filho W. 2007a. Geoprocessamento para caracterização do Alogrupo Alto Rio Paraná. Rev Bras Cartogr 59: 303-313.

Sallun AEM, Suguio K and Stevaux JC. 2007b. Proposição formal do Alogrupo Alto Rio Paraná (SP, PR e MS). Geologia, USP 7(2): 49-70.

Sallun AEM, Suguio K, Tatumi SH, Yee M, SAntos J AND BARRETO AMF. 2007c. Datação absoluta de depósitos quaternários brasileiros por luminescência. Rev Bras Geoc 37(2): 401-412.

Sallun AEM, Suguio K And Azevedo Sobrinho JM. 2008. Sedimentologia da Aloformação Paranavaí, Bacia Hidrográfica do Alto do Paraná (SP, PR e MS). Pesquisas Geoc 35: 85-107.

ShACKLETON NJ. 1997. The deep-sea sediment record and the Pliocene-Pleistocene boundary. Quatern Int 40: 33 35 .

SHACKLETON NJ AND OpdYKe ND. 1976. Oxygen isotope and paleomagnetic stratigraphy of Equatorial Pacific core V28-239, Late Pliocene to Latest Pleistocene. Geol Soc Am Mem 145: 499-464.

Shackleton NJ AND Pisias NG. 1985. Atmospheric carbon dioxide, orbital forcing, and climate. In: SUNDQUIST ET AND BROECKER WS (Eds), The carbon cycle and atmospheric $\mathrm{CO}_{2}$ : natural variations Archean to present. Geophys Mon 32: 412-417.

Shackleton NJ, Berger A And Peltier WR. 1990. An alternative astronomical calibration of the lower Pleistocene timescale based on ODP Site 677. Transactions of the Royal Society of Edimburgh, Earth Sciences 81: 251-261.

Shackleton NJ, Hall MA And Pate D. 1995. Pliocene stable isotope stratigraphy of Site 846. In: PISIAS NG ET AL. (Eds), Ocean Drilling Program, Scientific Results 138: 337-355. 
Shanley KW And MCCABE PJ. 1994. Perspectives on the sequence stratigraphy of continental strata. AAPG Bull 78: $544-568$

SoARES PC AND LANDIM PMB. 1976. Depósitos cenozóicos na região Centro-Sul do Brasil. Notas Geom 16(31): $17-39$.

Stevaux JC. 2000. Climatic events during the Late Pleistocene and Holocene in the Upper Paraná River: Correlation with NE Argentina and South-Central Brazil. Quatern Int 72: 73-85.

STOKES S. 1999. Luminescence dating applications in geomorphological research. Geomorphology 29: 153-171.

Suguio K, Nogueira JRJ, TANiguchi H And VAsconCELos ML. 1984. Quaternário no Rio Paraná em Pontal do Paranapanema: proposta de um modelo de sedimentação. In: Congresso Brasileiro DE GEOLOGIA, 33, Rio de Janeiro, RJ, Brasil. Anais, SBG, p. 10-18.
Tatumi SH, Gozzi G, Yee M, Oliveira Vi, Sallun AEM AND Suguio K. 2006. Luminescence dating of Quaternary deposits in geology in Brazil. Radiat Prot Dosim 119(1-4): 462-469.

Wells SG, MCFAdDEn LD AND Dohrenwend JC. 1987. Influence of late Quaternary climatic changes on geomorphic and pedogenic processes on a desert piedmont, eastern Mojave Desert, California. Quaternary Res 27: 130146.

Yanchou L, Prescott JR, Hua Z, Jie C and LanyING W. 2002. Optical dating of colluvial deposits from Xiyangfang, China, and the relation to palaeo-earthquake events. Quaternary Sci Rev 21(8-9): 1087-1097. 